\title{
Chemical composition of essential oils from the apiaceae family, cytotoxicity, and their antifungal activity in vitro against candida species from oral cavity
}

\author{
J. N. Vieira ${ }^{a}$, C. L. Gonçalves ${ }^{a}$, J. P. V. Villarreal ${ }^{a}$, V. M. Gonçalves ${ }^{b}$, R. G. Lund ${ }^{c}$, \\ R. A. Freitag ${ }^{b}$, A. F. Silva ${ }^{c}$ and P. S. Nascente ${ }^{a}$ \\ ${ }^{a}$ Laboratório de Parasitologia, Departamento de Microbiologia e Parasitologia, Institute de Biologia, \\ Universidade Federal de Pelotas - UFPel, s/n, Capão do Leão, CEP 96010-900, Pelotas, RS, Brasil \\ ${ }^{\text {b} D e p a r t a m e n t o ~ d e ~ Q u i ́ m i c a ~ O r g a ̂ n i c a, ~ U n i v e r s i d a d e ~ F e d e r a l ~ d e ~ P e l o t a s ~-~ U F P e l, ~ s / n, ~}$ \\ Capão do Leão, CEP 96010-900, Pelotas, RS, Brasil \\ ${ }^{\mathrm{c}}$ Departamento de Odontologia Restauradora, Faculdade de Odontologia, Universidade Federal de Pelotas - UFPel, \\ Ruas Chaves, 457, Centro, CEP 96020-080, Pelotas, RS, Brasil \\ *e-mail: jujununesvieira@yahoo.com.br
}

Received: July 3, 2017 - Accepted: January 27, 2018 - Distributed: August 31, 2019

(With 1 figure)

\begin{abstract}
The aims of this research were: evaluate the chemical composition and the cytotoxicity of the Cuminum cyminum (cumin), Anethum graveolens (dill), Pimpinella anisum (anise) and Foeniculum vulgare (fennel) essential oils, as well as their antifungal activity in vitro against ten Candida spp. isolates. The chemical composition of the oils was analyzed by means of gas chromatography coupled with mass spectrometry (GC/MS). The cytotoxicity assays were performed, using the cell proliferation reagent WST-1 in L929 mouse fibroblasts $\left(20 \times 10^{3}\right.$ well $\left.^{-1}\right)$. The determinate the Minimum Inhibitory Concentration (MIC), was performed through the Broth Microdilution technique (CLSI). The chemical main components were the cuminaldehyde (32.66\%) for cumin, carvone (34.89\%) for the dill, trans-anethole $(94.01 \%)$ for the anise and anethole $(79.62 \%)$ for the fennel. Anise and fennel did not were cytotoxic in all the tested concentrations, however the cumin oil was cytotoxic in the concentration of $20 \mathrm{mg} \cdot \mathrm{mL}^{-1}$ and the dill in the concentrations of 20 and $8 \mathrm{mg} \cdot \mathrm{mL}^{-1}$. All yeasts were susceptible against the evaluated essential oils. Cumin presented the lowest MIC against yeasts. We concluded that all the essential oils presented inhibitory action against Candida spp., and C. cyminum, P. anisum and $F$. vulgare were not cytotoxic in the same minimum inhibitory concentrations for the fungi.
\end{abstract}

Keywords: Cuminum cyminum, Chronic Atrophic Candidiasis, Candida spp., antifungal.

\section{Composição química de óleos essenciais da família apiaceae, citotoxicidade e sua atividade antifúngica in vitro contra espécies de candida da cavidade oral}

\begin{abstract}
Resumo
Os objetivos desta pesquisa foram: avaliar a composição química e a citotoxicidade dos óleos essenciais de Cuminum cyminum (cominho), Anethum graveolens (endro), Pimpinella anisum (erva-doce) e Foeniculum vulgare (funcho), bem como sua atividade antifúngica in vitro contra dez isolados de Candida spp.. A composição química dos óleos foi analisada por meio de cromatografia gasosa acoplada à espectrometria de massa (GC / MS). Os ensaios de citotoxicidade foram realizados, utilizando o reagente de proliferação celular WST-1 em fibroblastos de ratinho L929 (20x103 poço-1). A determinação da Concentração Inibitória Mínima (MIC) foi realizada através da técnica de microdiluição em caldo (CLSI). Os principais componentes químicos foram o cuminaldeído (32.66\%) para cominho, carvona (34.89\%) para o endro, trans-anetol (94.01\%) para erva-doce e anetol $(79.62 \%)$ para a funcho. O endro e a erva-doce não foram citotóxicos em todas as concentrações testadas, no entanto, o óleo de cominho foi citotóxico na concentração de $20 \mathrm{mg} \cdot \mathrm{mL}^{-1}$ e o endro nas concentrações de 20 e $8 \mathrm{mg} \cdot \mathrm{mL}^{-1}$. Todas as leveduras foram suscetíveis aos óleos essenciais avaliados. O cominho apresentou a menor CIM contra as leveduras. Concluímos que todos os óleos essenciais apresentaram ação inibidora contra Candida spp., e C. cyminum, P. anisum e F. vulgare não foram citotóxicos nas mesmas concentrações inibitórias mínimas para os fungos.
\end{abstract}

Palavras-chave: Cuminum cyminum, Candidíase atrófica crônica, Candida spp., antifúngico. 


\section{Introduction}

Candida spp. are the most common cause of fungal infections in humans, are important commensals microorganisms from the oral cavity, turning them pathogenic, if favorable conditions related to the host low immunity exist. Infections commonly known as oral candidiasis or moniliasis, have different clinical forms, such as pseudomembranous candidiasis, commonly known as thrush, erythematous candidiasis, hyperplastic and mucocutaneous candidiasis, being common problems faced by dental professionals (Simões et al., 2013).

Clinical Chronic Atrophic Oral Candidiasis or denture stomatitis is an erythematous oral candidiasis, characterized by different degrees of erythema and hemorrhagic petechiae, localized in the edge of the denture area of a superior removable prosthesis. This reaction can result from; an inappropriate denture design, an allergy at its base or by an acrylic inadequate polymerization (Moreira et al., 2002).

In the last decade, the infections by Candida species had been growing in an alarming speed, as well as their resistance development towards antifungal drugs commonly used with unwished reactions in patients. There by, new alternative products are proposed to minimized such of these negative facts (Lima et al., 2006; Pozzatti, 2007).

By the above, fitotherapic alternatives, such as essential oils, have entered into the market, with the purpose to reduce the costs of production, this is why rigorous tests are required to control their quality in relation to their effectiveness, antimicrobial activity, security and toxicity when compared to others types of synthetic drugs, as well as the reduce the side effects in patients (Castro and Lima, 2010; Kamble, 2015).

Among the many species of aromatic plants, the ones from the family Apiaceae had been investigated for medical use, due to their antimicrobial properties. These plants produce essential oils, characterized for releasing a relative high amount of volatile compounds (Simões et al., 2010). Among some representatives species of the Apiaceae family, we can mention; the Cuminum cyminum (cumin), Anethum graveolens (dill), Pimpinella anisum (anise) and Foeniculum vulgare (fennel) and the fennel (Foeniculum vulgare), plants with culinary and medical applications (Downie et al., 2000).

The aim of this research was to evaluate the cytotoxicity and chemical composition of the C.cyminum, A. graveolens, $P$. anisum and $F$. vulgare essential oils, as well as their in vitro antifungal activity against Candida spp. isolates from clinical Chronic Atrophic Oral Candidiasis cases.

\section{Material and Methods}

\subsection{Research location and fungal isolates}

The microbial assays were performed in the Laboratory of Mycology located in the Biology Institute from the Federal University of Pelotas (UFPel). The isolates tested were obtained from the mycology collection of the Oral Microbiology Laboratory in the Faculty of Odontology, from clinical Chronic Atrophic Oral Candidiasis cases, being the following Candida species: Candida albicans (23778, 23651, 23609, 24073 e 23536), Candida parapsilosis (2340 e 23459), Candida glabrata (23453), Candida krusei (23932) and C. albicans ATCC (62342).

\subsection{Essential oils}

The C. cyminum, A. graveolens, $P$. anisum and $F$. vulgare essential oils were obtained through the Department of Organic Chemistry of the Chemical Science, Pharmaceutics and Food Center (CCQFA) of the UFPel, by means of hydrodistillation $\left(1.5 \mathrm{~L}\right.$ of distilled $\mathrm{H}_{2} \mathrm{O} / 100 \mathrm{~g}$ of plant material) in a Clevenger apparatus. The plants were commercially acquired from the Luar Sul L.T.D.A., company and the parts used were: seeds, for the cumin, dill and anise; and leaves for the fennel. The essential oil yield for each plant was of $2.5 \mathrm{~mL}$ for the cumin and anise, $1.9 \mathrm{~mL}$ for the dill and $2.3 \mathrm{~mL}$ for the fennel.

\subsection{Chromatographic analysis of the essential oils}

The essential oils were submitted to chromatography analysis coupled with mass spectrometry (GC/MS) in a Schimadzu QP2010 apparatus, equipped with split/splitless injector with capillary column Rtx-5MS $\operatorname{RESTEK}(30 \mathrm{~m} \times 0,25 \mathrm{~mm} \times 0,25 \mu \mathrm{m})$, in the following chromatographic conditions: Helium gas as carrier, obtained fragments by the impact of the electrons at the energy of $70 \mathrm{eV}$, flow $1.2 \mathrm{ml} / \mathrm{min}$, split $1: 10,1 \mu \mathrm{L}$ of sample injected volume. Oven programmed temperature: Initial temperature of $40{ }^{\circ} \mathrm{C}$, with a heating ramp at $5{ }^{\circ} \mathrm{C} / \mathrm{min}$ to $280{ }^{\circ} \mathrm{C}$, remaining stable in this temperature for 10 minutes, with a total time of 8 minutes, being the injector temperature of $58^{\circ} \mathrm{C}$ and the interface of $200^{\circ} \mathrm{C}$. The compounds were analyzed according to the chromatographic standards, based on the GC/MS NIST08 library. The oil was diluted in hexane (analytical grade, ultra-pure).

\subsection{Cytotoxicity assay}

The cytotoxicity assay was realized by the Department of Restorative Dentistry, School of Dentistry, from the Federal University of Pelotas (UFPel). The cell viability was performed according to the ISO 10993-5 (ISO, 2009). Mouse fibroblasts cell line L929 $\left(20 \times 10^{3}\right.$ well $\left.^{-1}\right)$ were maintained in Dulbeccos's Modified Eagle Medium (DMEM) supplemented with $10 \%$ of fetal bovine serum (FBS), $2 \%$ of L -glutamine, penicillin (100 U.ml-1) and streptomycin (100 mg.ml ${ }^{-1}$ ) using a plate of 96-wells, incubated for 24 $\mathrm{h}$ at $37^{\circ} \mathrm{C}$ in a humidified atmosphere of $\mathrm{CO} 25 \%$ in air until sub confluence was achieved. The essential oils were made by a mold (6 $\mathrm{mm}$ diameter and $1 \mathrm{~mm}$ depth), and photo-activated by Radii Cal $(n=5)$. The essential oils were diluted and tested at concentrations of 20, 8, 4 e $2 \mathrm{mg} \cdot \mathrm{mL}^{-1}$. After 24 hours, $200 \mu \mathrm{l}$ of each dilution oils were transferred to the 96-well plates previously prepared and incubated for $24 \mathrm{~h}$. WST-1 assay was used to assess cell metabolic function by mitochondrial dehydrogenase activity. The absorbance at $450 \mathrm{~nm}$ was measured via a microplate reader (SpectraMax M5; Molecular Devices, Sunnyvale, CA, USA). Each assay was performed in triplicate. 
Statistical analysis was performed using Kruskal-Wallis (One Way Analysis of Variance on Ranks) followed by Turkey complementary test. Cell viability values above $70 \%$ indicate that the chemical compound was not cytotoxic, according ISO 10993-5 (2009).

\subsection{Minimum Inhibitory Concentration (MIC)}

The determination of the Minimum Inhibitory Concentrations of the essential oils was performed using the Broth Microdilution technique, in accordance with the document M27-A4 by the Clinical and Laboratory Standards Institute (Clinical and Laboratory Standards Institute, 2013), adapted to phyto pharmaceuticals. Initially, $100 \mu \mathrm{L}$ of RPMI media - 1640 (DIFCO ${ }^{\circledR}$, Detroit, Michigan, EUA) were distributed in each well of the microdilution plate which contains 96 wells with a "U" bottom form. For the MIC evaluation of the essential oils, 10 successive dilutions in RPMI medium were performed; obtaining concentrations of 70 to $0.137 \mathrm{mg} \cdot \mathrm{mL}^{-1}$, arranged in a volume of $100 \mu \mathrm{L}$ according to the sense of the lines in the microdilution plate. In the each well of each column, aliquots of $100 \mu \mathrm{L}$ of each inoculum of each corresponding Candida species were added, for further analysis. The yeast's suspension was adjusted in a spectrophotometer $(530 \mathrm{~nm})$ to obtain a final concentration of approximately $5 \times 10^{6}$ cells $\mathrm{mL}^{-1}$.

The tests were performed by duplicate, with three repetitions; a column used for the positive control (inoculum/medium) and another column for the negative control (essential oil/medium).

Jointly the same procedure was performed with the fluconazole, considered a model in clinical use, in successive concentrations, from $16 \mu \mathrm{g} \cdot \mathrm{mL}^{-1}$ to $0.0313 \mu \mathrm{g} \cdot \mathrm{mL}^{-1}$ (Clinical and Laboratory Standards Institute, 2013), by the microdilution technique.

The microplates were incubated at $35^{\circ} \mathrm{C}$ for 48 hours. The lecture for the MIC determination of the essential oils against the yeasts strains was performed through turbidity visualization, related to the microorganism growth and compared to the positive and negative controls. It was considered as MIC, the minor concentration of the drug capable to produce growth inhibition of the yeasts, compared with the positive control well (Clinical and Laboratory Standards Institute, 2013).

\section{Results}

In Table 1, the majority compound present in the cumin essential oil was the cuminaldehyde (32.66\%), for the dill the carvone $(34.89 \%)$, for the anise the trans-anethole $(94.01 \%)$ and for the fennel the anethole (79.62\%).

In the present study, cytotoxicity assays showed that only cumin and dill oils were cytotoxicity, since present below of $70 \%$ of cell viability (Figure 1 ). In relation to the yeasts' MIC, the cumin, anise and fennel did not shown

Table 1. Main chemical compounds identified in the Cuminum cyminum, Anethum graveolens, Pimpinella anisum and Foeniculum vulgare essential oils, using the chromatography GC/MS technic.

\begin{tabular}{|c|c|c|c|c|}
\hline \multirow{2}{*}{ Chemical Compounds } & \multicolumn{4}{|c|}{ Essential Oils } \\
\hline & Cumin & Dill & Anise & Fennel \\
\hline Cuminaldehyde & $32.66 \%$ & & & \\
\hline$\gamma$-terpinene & $19.87 \%$ & & & \\
\hline$\beta$-pinene & $15.22 \%$ & & & \\
\hline o-cymene & $14.00 \%$ & & & \\
\hline 2-caren-10-al & $8.54 \%$ & & & \\
\hline 1-fenil-1-butanol & $8.01 \%$ & & & \\
\hline D-limonene & $1.7 \%$ & $18.92 \%$ & & \\
\hline trans-anethole & & & $94.01 \%$ & \\
\hline Estragole $c i s$-anethole & & & $2.46 \%$ & $3.65 \%$ \\
\hline cis-(-)-2,4a,5,6,9a-Hexahydro-3,5,5,9- & & & $1.7 \%$ & \\
\hline tetramethyl $(1 \mathrm{H})$ benzocycloheptene $c i s$-anethole & & & $0.83 \%$ & \\
\hline$(+)$-Carvone & & & $0.29 \%$ & \\
\hline Di-epi-alpha-cedrene & & & $0.24 \%$ & \\
\hline Limonene & & & $0.18 \%$ & \\
\hline p-Cumic aldehyde & & & $0.16 \%$ & \\
\hline beta-Chamigrene & & & $0.13 \%$ & \\
\hline Carvone & & $34.89 \%$ & & \\
\hline Apiol & & $22.02 \%$ & & \\
\hline Dihydrocarvone & & $16.91 \%$ & & \\
\hline Trans-dihydrocarvone Anethole & & $7.26 \%$ & & $79.62 \%$ \\
\hline Fenchone & & & & $12.19 \%$ \\
\hline Methyl nonadecanoate & & & & $2.89 \%$ \\
\hline 1R- $\alpha$-pinene & & & & $1.65 \%$ \\
\hline
\end{tabular}


cytotoxicity, however the dill oil in the concentrations of 20 and $8 \mathrm{mg} \cdot \mathrm{mL}^{-1}$ were cytotoxic related to the MIC.

The antifungal tests with ten Candida species demonstrated that all tested yeasts showed susceptibility against the evaluated essential oils, being that the cumin (Cuminum cyminum) essential oil, showed the best antifungal activity, with the lowest MICs, that varied from 2.188 to $4.375 \mathrm{mg} . \mathrm{mL}^{-1}$. The essential oil of fennel (Foeniculum vulgare) also showed low minimum inhibitory concentration (MIC: $4.375 \mathrm{mg} \cdot \mathrm{mL}^{-1}$ ) against Candida albicans isolate (24073), however, this was equal to the CMI verified for cumin (Table 2).

\section{Discussion}

Due to the problems faced by patients carrying oral candidiasis, especially clinical Chronic Atrophic oral Candidiasis, mainly by the Candida species resistance against antifungal drugs commonly use, the search of new compounds, such as essential oils, which have antimicrobial actions against resistant microorganisms, are necessary. As result of the present study, it was verified that the essential oils of $C$. cyminum, A. graveolens, $P$. anisum and $F$. vulgare showed antifungal activity against ten

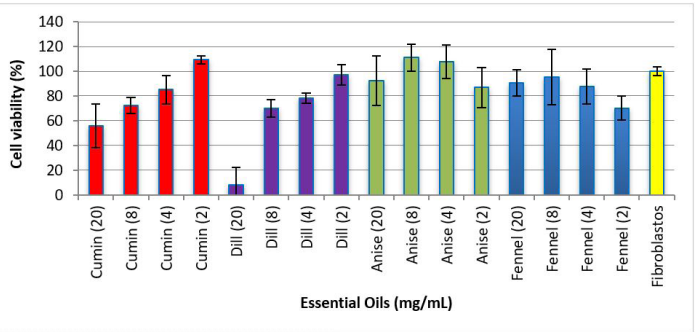

Figure 1. Cytotoxicity activity in vitro of the Cuminum cyminum, Anethum graveolens, Pimpinella anisum and Foeniculum vulgare essential oils in Mouse fibroblasts L929 $\left(20 \times 10^{3}\right.$ well $\left.^{-1}\right)$ cells.

Table 2. Inhibitory Minimum Concentration (mg. $\left.\mathrm{mL}^{-1}\right)$ of the Cuminum cyminum, Anethum graveolens, Pimpinella anisum and Foeniculum vulgare essential oils against the ten Candida species isolates.

\begin{tabular}{lcccc}
\hline \multicolumn{1}{c}{ Essential Oils } & \multirow{2}{c}{ Cumin } & Dill & Anise & Fennel \\
\hline $\begin{array}{l}\text { C. albicans ATCC } \\
\text { (62342) }\end{array}$ & 8.75 & 8.75 & 8.75 & 8.75 \\
C. albicans (23778) & 4.375 & 8.75 & 8.75 & 8.75 \\
C. albicans (23651) & 4.375 & 8.75 & 8.75 & 8.75 \\
C. albicans (23609) & 4.375 & 8.75 & 8.75 & 8.75 \\
C. albicans $(24073)$ & 4.375 & 8.75 & 8.75 & 4.375 \\
C. albicans $(23536)$ & 4.375 & 8.75 & 8.75 & 8.75 \\
C. parapsilosis (2340) & 4.375 & 8.75 & 8.75 & 8.75 \\
C. parapsilosis (23459) & 2.188 & 8.75 & 8.75 & 8.75 \\
C. glabrata (23453) & 4.375 & 17.5 & 8.75 & 8.75 \\
C. krusei (23932) & 4.375 & 8.75 & 8.75 & 8.75 \\
\hline
\end{tabular}

tested oral Candida species, all isolates were sensitive to the synthetic antifungal fluconazole, used as control.

Several studies have shown the excellent therapeutic properties of essential oils, meanwhile, in the assays of antifungal in vitro activity of the oils, it is possible to verified a variety of methodologies proposed, such are the agar diffusion, the disk diffusion and the broth dilution (Kosalec et al., 2005; Gulfraz et al., 2008; Pai et al., 2010; Wanner et al., 2010; Cavalcanti et al., 2011; Cleff et al., 2013; Kamble, 2015), making hard to compared between the present study and these studies. There by, the recognition of the pharmacologic activity of the presented plants in this study represents important information to evaluate the obtained viability of the product in clinical use.

In our results, the C.cyminum essential oil had the lowest inhibitory concentration against Candida species, compared to the other oils. Results with inhibition values and good antimicrobial activity of C. cyminum, against the Candida species, were also registered by other authors. Shetty et al. (1994), using the agar diffusion method, founding positive results, however with a minor inhibitory concentration of 0,10 mg.mL ${ }^{1}$. Pai et al. (2010) and Wanner et al. (2010) used the disk diffusion method, confirming the cumin as an anti-Candida potential agent. Kamble (2015), had good inhibition results against Candida albicans and not albicans using the disk diffusion and the broth micro and macrodilution techniques (Minimum Inhibitory Concetration).

C. parapsilosis (23459) had the highest susceptibility against cumin essential oil (CIM de 2,188 mg.mL $\mathrm{mL}^{-1}$ ), meanwhile the others isolates showed inhibition at higher concentrations, to this and the others essential oils.

In the dill, anise and fennel essential oils, the antifungal activity was practically the same against Candida spp. isolates, having few variations. In other works using the dill essential oil, the antifungal activity against $A$. graveolens was analyzed and confirmed against the Candida spp. clinical isolates. In the study by Zeng et al. (2011), using the broth microdilution technic (MIC), microbiological and histological technics in mice, demonstrated that dill was active in vitro and in vivo against all the Candida species tested. Yili et al. (2009), analyzed the MIC through the Barry method, with an ethylene oxide addition, and they found inhibition results of $0.00273 \mathrm{mg} \cdot \mathrm{mL}^{-1}$ in C. albicans, affirming that the yeast growth, sharply decreased with this component addition in the nutrient medium.

In studies using anise, Kosalec et al. (2005), evaluated the antifungal activity of the extract fluid and essential oil of $P$. anisum in Candida species, through the agar diffusion and broth dilution methods and verified that the essential oil exhibit a low minimum inhibitory concentration in vitro against yeasts.

As for the fennel essential oil, Gulfraz et al. (2008) and Pai et al. (2010) also confirmed the effective antifungal effect of the oil of $F$. vulgare against $C$. albicans, through the disk diffusion method, however, Skrobonja et al. (2013), in one of the used technics, found results in vitro with MICs of 0.06 and $0.02 \mathrm{mg}$. $\mathrm{mL}^{-1}$ against this yeast. 
In this research, the antifungal activity determination of the oils was performed through the broth microdilution technic (Clinical and Laboratory Standards Institute, 2013), with the aim to proportionate a major contact between the tested products and the fungic cells (Cavalcanti et al., 2011), being the MIC obtained one of the better patterns in evaluating the antifungal activity of the essential oils (Pozzatti, 2007).

According to Menezes et al. (2009) and Cavalcanti et al. (2011), vegetal products with good antimicrobial activity must present a MIC equal or inferior to $100 \mathrm{mg} \cdot \mathrm{mL}^{-1}$, and in the present study, $97.5 \%$ of essential oils were equal to or below $8.75 \mathrm{mg} \cdot \mathrm{mL}^{-1}$, demonstrating an adequate inhibitory activity in low concentrations and appropriate antifungal activity, with the application capacity of these compounds as antimicrobial substances in dental practice.

The higher and lower biological activity of the essential oils has been dependent to its composition, in other words of his chemicals constituents (Lima et al., 2006).

Elevated concentrations of these constituents and their proportions are of great importance in the product efficacy, confirming their properties and medicals applications. However, studies demonstrated that these isolated compounds don't have the same efficacy of the essential oil (Simões et al., 2010; Yili et al., 2009).

In the chromatographic analysis of the C. cyminum essential oil, the majority constituents were Cuminaldehyde, $\gamma$-terpinene, $\beta$-pinene, $o$-cymene, 2 -caren-10-al, 1-phenyl1 -butanol and D-limonene agreeing with the results found by others authors, only with few variations (Shetty et al., 1994; Wanner et al., 2010; Kamble, 2015).

In the chromatography analysis of the essential oil of $A$. graveolens, the principal identified constituents were Carvone, Apiol, D-limonene, Dihydrocarvone and Trans-dihydrocarvone agreeing with the studies by Zeng et al. (2011); Tian et al. (2011), featuring the carvone, limonene and apiol as the majority compounds.

In the essential oil of $P$. anisum, the principal compounds found were trans-anethole and Estragole. Other constituents of the oil present in lower quantity were cis-(-)-2,4a,5,6,9a-Hexahydro-3,5,5,9-tetramethyl $(1 \mathrm{H})$ benzocycloheptene, cis-anethole, (+)-Carvone, Di-epi-alpha-cedrene, Limonene, p-Cumic aldehyde and beta-Chamigrene. Similar results were reported in other Works (Shojaii and Fard, 2012; Ozcan and Chalchat, 2006).

In the chromatography result of $F$. vulgare, the following constituents were verified in higher quantity: Anethole, Fenchone, Estragol, methyl nonadecanoate and 1R- $\alpha$-pinene. Other studies also confirmed such identified components as the main (Anwar et al., 2009; Peixoto et al., 2014).

The antimicrobial activity of the essential oils is attributed to their principal components and to the resulted synergic or antagonist action. However, the minor components also contribute to their biologic activity (Iacobellis et al., 2005).

In the present study, the cell viability test WST-1 in the Mouse fibroblasts L929 $\left(20 \times 10^{3}\right.$ well $\left.^{-1}\right)$ was made for cytotoxicity evaluation. We sought, with this analysis; information in relation to the biological behavior of the oils, so that they can subsequently be used for in vivo studies. The cytotoxicity evaluation provides a security parameter in the compounds utilization having potential therapeutic activity (Yamaguchi et al., 2013). As for the cytotoxicity assay, the oils of cumin, anise and fennel were not cytotoxic in the same minimum inhibitory concentrations found for the tested yeast Such results suggest that these oils showed to be promising models in the selection of natural products with antifungal activity, to prevent and treat fungal infections in oral tissue.

Given the above, it is possible note the need to investigate the potential application of these phytotherapeutic oils in the formulation of dental products such as in the prevention and treatment of candidiasis on dental prostheses, which indicates conducting further research to knowlegde the effectiveness of these oil constituents in the formulation of these new dental products.

The essential oils of different species of the Apiaceae family, proved to be a promising source of biomolecules, with antifungal potential activity. Inside the experimental conditions of the present study, it was possible to conclude that the C. cyminum essential oil exhibit the lowest MIC against the tested Candida species, and cumin, anis and fennel essential oils were not cytotoxic to Mouse fibroblasts in the same minimum inhibitory concentrations found for the tested yeast. However, other specific in vivo studies and clinical assays about the security and efficacy of these oils are necessary, to evaluate the relevance practice of the results obtained in vitro, for the future development of new products with possible therapeutic applications.

\section{References}

ANWAR, F., ALI, M., HUSSAIN, A.I. and SHAHID, M.J., 2009. Antioxidant and antimicrobial activities of essential oil and extracts of fennel (Foeniculum vulgare Mill.) seeds from Pakistan. Flavour and Fragrance Journal, vol. 24, no. 4, pp. 151-207. http://dx.doi.org/10.1002/ffj.1929.

CASTRO, R.D. and LIMA, E.O., 2010. Atividade antifúngica in vitro do óleo essencial de Eucalyptus globulus L. sobre Candida spp. Revista de Odontologia da UNESP, vol. 39, pp. 179-184.

CAVALCANTI, Y.W., PÉREZ, A.L.A.L., XAVIER, G.D.R. and ALMEIDA, L.F.D., 2011. Efeito inibitório de óleos essenciais sobre microrganismos do canal radicular. Revista de Odontologia da UNESP, vol. 40, pp. 208-214.

CLEFF, M.B.C., MADRID, I., MEINERZ, A.R., MEIRELES, M.C.A., MELLO, J.R.B., RODRIGUES, M.R. and ESCAREÑO, J.J.H., 2013. Essential oils against Candida spp: in vitro antifungal activity of Origanum vulgare. African Journal of Microbiological Research, vol. 7, no. 20, pp. 2245-2250. http://dx.doi.org/10.5897/ AJMR12.1149.

CLINICALAND LABORATORY STANDARDS INSTITUTE, 2013. Method for broth dilution antifungal susceptibility testing of yeasts: approved standard. 3rd ed. Wayne: CLSI. M27-A3.

DOWNIE, S.R., KATZ-DOWNIE, D.S. and SPALIK, K., 2000. A Phylogeny of Apiaceae tribe scandiceae: evidence from nuclear ribosomal dna internal transcribed spacer sequences. 
American Journal of Botany, vol. 87, no. 1, pp. 76-95. http:// dx.doi.org/10.2307/2656687. PMid:10636832.

GULFRAZ, M., MEHMOOD, S., MINHAS, N., JABEEN, N., KAUSAR, R., JABEEN, K. and ARSHAD, G., 2008. Composition and antimicrobial properties of essential oil of Foeniculum vulgare. African Journal of Biotechnology, vol. 7, pp. 4364-4368.

IACOBELLIS, N.S., CANTORE, P., CAPASSO, F. and SENATORE, F., 2005. Antibacterial Activity of Cuminum cyminum L. and Carum carvi L. Essential Oils. Journal of Agricultural and Food Chemistry, vol. 53, no. 1, pp. 57-61. http://dx.doi. org/10.1021/jf0487351. PMid:15631509.

INTERNATIONAL ORGANIZATION FOR STANDARDIZATION - ISO, 2009. Biological evaluation of medical devices - Part 5: tests for in vitro cytotoxicity. Vernier: ISO. STANDARD 10993-5:2009(E).

KAMBLE, V.A., 2015. In vitro Anti-Fungal Activity of Cuminum cyminum (Cumin Seed) Essential Oil against Clinical Isolates of Candida Species. American Journal of Phytomedicine and Clinical Therapeutics, vol. 3, pp. 264-275.

KOSALEC, I., PEPELJNJAK, S. and KUSTRAK, D., 2005. Antifungal activity of fluid extract and essential oil from anise fruits (Pimpinella anisum L., Apiaceae). Acta pharmaceutica (Zagreb, Croatia), vol. 55, no. 4, pp. 377-385. PMid:16375827.

LIMA, I.O., OLIVEIRA, R.A.G., LIMA, E.O., FARIAS, N.M.P. and SOUZA, E.L., 2006. Atividade antifúngica de óleos essenciais sobre espécies de Candida. Revista Brasileira de Farmacognosia, vol. 16, no. 2, pp. 197-201. http://dx.doi.org/10.1590/S0102$695 \times 2006000200011$

MENEZES, T.O.A., ALVES, A.C.B.A., VIEIRA, J.M.S., MENEZES, S.A.F., ALVES, B.P. and MENDONÇA, L.C.V., 2009. Avaliação in vitro da atividade antifúngica de óleos essenciais e extratos de plantas da região amazônica sobre cepa de Candida albicans. Revista de Odontologia da UNESP, vol. 38, pp. 184-191.

MOREIRA, A.C.A., FALCÃO, A.F.P., ANDRADE, A.P.A. and SOUZA, E.R., 2002. Isolamento de Candida parapsilosis em paciente com diagnóstico clínico de candidíase atrófica crônica. Revista de Ciências Médicas e Biológicas, vol. 1, no. 1, pp. 124128. http://dx.doi.org/10.9771/cmbio.v1i1.4250.

OZCAN, M.M. and CHALCHAT, J.C., 2006. Chemical composition and antifungal effect of anise (Pimpinella anisum L.) fruit oil at ripening stage. Annals of Microbiology, vol. 56, no. 4, pp. 353358. http://dx.doi.org/10.1007/BF03175031.

PAI, M.B.H., PRASHANT, G.M., MURLIKRISHNA, K.S., SHIVAKUMAR, K.M. and CHANDU, G.N., 2010. Antifungal efficacy of Punica granatum, Acacia nilotica, Cuminum cyminum and Foeniculum vulgare on Candida albicans: An in vitro study. Indian Journal of Dental Research, vol. 21, no. 3, pp. 334-336. http://dx.doi.org/10.4103/0970-9290.70792. PMid:20930339.

PEIXOTO, J.V., ROCHA, M.G., NASCIMENTO, R.T.L., MOREIRA, V.V. and KASHIWABARA, T.G.B., 2014. Candidíase - uma revisão de literatura. Brazilian Journal of Surgery and Clinical Research, vol. 8, pp. 75-82.
POZZATTI, P., 2007. Suscetibilidade de Candida spp sensiveis e resistentes ao fluconazol frente a óleos essenciais extraídos de condimentos. Santa Maria: Centro de Ciências da Saúde, Universidade Federal de Santa Maria, 148 p. Dissertação de Mestrado, Área de Concentração em Ciências Farmacêuticas.

SHETTY, R.S., SINGHAL, R.S., and KULKARNI, P.R., 1994. Antimicrobial properties of cumin. World Journal of Microbiology \& Biotechnology, vol. 10, no. 2, pp. 232-233. http://dx.doi. org/10.1007/BF00360896. PMid:24420956.

SHOJAII, A. and FARD, M.A., 2012. Review of pharmacological properties and chemical constituents of Pimpinella anisum. ISRN Pharmaceutics, vol. 2012, pp. 510795. PMid:22848853.

SIMÕES, C.M.O., SCHENKEL, E.P., GOSMANN, G., MELLO, J.C.P. and MENTZ, L.A., 2010. Farmacognosia: da planta ao medicamento. 6. ed. Porto Alegre: UFRGS.

SIMÕES, R.J., FONSECA, P. and FIGUEIRAL, M.H., 2013. Infecções por Candida spp na Cavidade Oral. Odontologia Clínico-Científico, vol. 12, pp. 19-22.

SKROBONJA, J.R., DELIC, D.N., KARAMAN, M.A., MATAVULJ, M.N. and BOGAVAC, M.A., 2013. Antifungal properties of Foeniculum vulgare, carum carvi and Eucalyptus sp. essential oils against Candida albicans strains. Journal Natural Science, vol. 124, pp. 195-202.

TIAN, J., BAN, X., ZENG, H., HUANG, B., HE, J. and WANG, Y., 2011. In vitro and in vivo activity of essential oil from dill (Anethum graveolens L.) against fungal spoilage of cherry tomatoes. Food Control, vol. 22, no. 12, pp. 1992-1999. http:// dx.doi.org/10.1016/j.foodcont.2011.05.018.

WANNER, J., BAIL, S., JIROVETZ, L., BUCHBAUER, G., SCHMIDT, E., GOCHEV, V., GIROVA, T., ATANASOVA, T. and STOYANOVA, A., 2010. Chemical composition and antimicrobial activity of cumin oil (Cuminum cyminum, Apiaceae). Natural Product Communications, vol. 5, no. 9, pp. 1355-1358. PMid:20922990.

YAMAGUCHI, K.K.L., VEIGA-JUNIOR, V.F., PEDROSA, T.N., VASCONCELLOS, M.C. and LIMA, E.S., 2013. Atividades biológicas dos óleos essenciais de Endlicheria citriodora, uma Lauraceae rica em geranato de metila. Quimica Nova, vol. 36, no. 6, pp. 826-830. http://dx.doi.org/10.1590/S0100-40422013000600015.

YILI, A., AISA, H.Á., MAKSIMOV, V.V., VESHKUROVA, O.N. and SALIKHOV, S.I., 2009. Chemical composition and antimicrobial activity of essential oil from seeds of Anethum graveolens growing in Uzbekistan. Chemistry of Natural Compounds, vol. 45, no. 2, pp. 280-281. http://dx.doi.org/10.1007/ s10600-009-9275-4.

ZENG, H., TIAN, J., ZHENG, Y., BAN, X., ZENG, J., MAO, Y. and WANG, Y.J., 2011. In viro and in vivo activities of essential oil from the seed of Anethum graveolens L. against Candida spp. Evidence-Based Complementary and Alternative Medicine, vol. 2011, pp. 659704. http://dx.doi.org/10.1155/2011/659704. PMid:21716714. 